\title{
Basic Quality Management for Improving the Business Stability of Small Food Enterprises in Southeast Asia: The Case of a Fermented Rice Noodle Company in Thailand Preventing Noodle Liquefaction
}

\author{
Eiichi KUSANO*, Junichiro MARUI and Tadashi YOSHIHASHI \\ Japan International Research Center for Agricultural Sciences, Tsukuba, Japan
}

\begin{abstract}
This study investigates the impact of basic quality management on the product quality and profitability of small- and medium-sized Thai fermented rice noodle (khanom jeen) manufacturers. Specifically, an interview survey of a small-scale khanom jeen producer in Thailand was conducted to highlight the effects of sudden noodle liquefaction during manufacture on profitability and determine the cost of implementing a liquefaction risk management system. This case study shows that systemized basic quality management can help conventional small- and medium-sized manufacturers to stabilize their product quality and business management. Moreover, specific techniques based on the latest findings in the field of food science can also be adopted to prevent the liquefaction problem.
\end{abstract}

Discipline: Social Science

Additional key words: breakeven analysis, cost-volume-profit analysis, food technology, khanom jeen, $\mathrm{pH}$ control

\section{Introduction}

Small- and medium-sized enterprises (SMEs) perform essential roles in promoting economic activity, and thus are viewed as critical players for domestic development, especially in low-income developing countries (OECD \& World Bank 2017). Thailand's small food and beverage enterprises are defined as companies employ fewer than 50 workers and have fixed assets worth less than $\$ 165,017$. Accounting for $99.0 \%$ of all enterprises in the food and beverage sector in Thailand, small enterprises employed $56.4 \%$ of the total workforce in the sector in 2017 (OSMEP 2018). ${ }^{1}$

As is often argued in innovation studies, the adoption of new technology is a critical factor in responding to the demand for food and improving the industry's competitiveness (Vyas 2015). However, such studies tended to focus on high-technology industries

${ }^{1} \$ 1 \approx 30.3$ Thai Baht in November 2019. Fixed assets do not include land. and established firms, rather than low-technology SMEs that account for the vast majority of businesses in developing countries (Baregheh et al. 2012, 2014, Vyas 2015). Although these studies have actively explored the universal factors related to the adoption or success of an innovation, the information available on these individual technologies and their contexts is often too generalized to be applicable (Huq \& Toyama 2006, Vyas 2015).

Several studies have examined the factors affecting the adoption and success of new technology, particularly for product innovation and new product development (NPD). However, there is limited research focusing on small food enterprises (Baregheh et al. 2012, 2014, Suwannaporn \& Speece 2010, Vyas 2015). Studies targeting the Thai food industry have mainly examined the factors critical for successful NPD or the performance of high technological capabilities (Huq \& Toyama 2006, Ngamkroeckjoti et al. 2005, Suwannaporn \& Speece 2010). Meanwhile, introducing or improving basic quality management may be more feasible than making innovative changes in the products of

\footnotetext{
*Corresponding author: kusano11@affrc.go.jp

Received 20 May 2020; accepted 25 September 2020.
} 
low-technology SMEs in the food industry (Dale 2003, Fryer \& Versteeg 2008).

This study focuses on a specific issue requiring techniques based on the latest findings in the field of food science: improvement in the food quality of khanom jeen noodles made using fermented rice flour in Thailand. There are several large rice producers in Southeast Asian countries such as Indonesia, Myanmar, Thailand, and Vietnam. The stable production of processed rice foods would increase the added value of rice-related industries that employ many workers in this region. Moreover, fermented rice noodles are widely consumed in Southeast Asia. In Thailand, 12\% of the people consume fermented rice noodles at an average daily rate of $185 \mathrm{~g}$ per person, according to a nationwide survey of 19,046 persons conducted during 2002-2005 (ACFS 2010). A well-known problem with noodle production is the sudden noodle liquefaction soon after production, which severely affects business and undermines buyer confidence. According to interviews held with noodle producers, a typical response to this problem is the replacement of raw materials such as rice and flour. Despite such a severe problem, few studies are reported on khanom jeen from economic or marketing aspects, except for several case studies that analyze the effects of marketing mix on customer satisfaction (Dasthanim 2018, Roungchong et al. 2020).

The study conducted a case study of a small-scale khanom jeen factory located in the Bangkok Metropolitan Region, in order to evaluate the effects of liquefaction on the profitability of small-scale rice and noodle producers, and determine the cost of preventing the problem. The evaluation mainly used cost-volume-profit analysis. This case study concludes that food product quality can be stabilized using systemized basic quality management, depending on available concrete technologies, appropriate equipment to implement it, and associated costs. It also provides practical information on easing the problems faced by conventional, smallscale khanom jeen producers, highlights the relationship between food science and agribusiness management, and supplements previous works that discussed the adoption of technology in more generalized ways.

\section{Fermented rice noodles and the liquefaction problem}

Fermented rice noodles are made by extruding fermented rice flour dough in boiling water. The noodle products generally retain their quality for a few days if kept at ambient temperature. The noodles cannot be refrigerated without the risk of starch retrogradation and loss of unique texture (Marui et al. 2020). Given such product characteristics, small-scale, conventional khanom jeen producers are thus expected to run their businesses near local markets across the country. As large-scale modern retailers and restaurants are not major trading partners, they face weak pressure to upgrade, such as for process control.

The median number of workers registered with the Department of Industrial Works, Ministry of Industry (DIW 2019), in firms producing only flour, only noodles, and both flour and noodles are 8, 7, and 10, respectively. The production of small-scale fermented rice flour and noodle manufacturers depends on their experience in functioning in buildings open to the environment. However, such an environment could result in unstable quality and sudden noodle liquefaction (Oupathumpanont et al. 2019).

The direct cause of liquefaction is of scientific interest, with several studies being made to find ways of preventing the problem. Marui et al. (2020) found that khanom jeen liquefaction was induced by the increased $\mathrm{pH}$ level of noodles due to treatment with weak acidic ( $\mathrm{pH}$ 6) or alkaline ( $\mathrm{pH} 8$ ) buffers; however, liquefaction was not induced when acidic ( $\mathrm{pH} 4)$ buffers were used (Marui et al. 2020). Generally, khanom jeen noodles made from fermented rice flour exhibit an acidic $\mathrm{pH}$ level of 4 or less, as the production process reduces the $\mathrm{pH}$ level (Uchimura et al. 1991). Thus, managing the $\mathrm{pH}$ level can be a method of preventing noodle liquefaction.

\section{Case study of a fermented rice flour and noodles producer}

\section{General information on Factory $A$}

We conducted an interview survey of a small-scale fermented rice flour and noodles producer (hereafter, "Factory A") in 2019 to clarify the liquefaction effect on profitability. Factory A is located in the Bangkok Metropolitan Region. Established as a fermented rice flour company in 2014, it launched its noodle production by the end of 2018. The number of employees engaged in producing flour, producing noodles, and delivering the products is 13,6 , and 4 , respectively. The total number of employees (23) exceeds the median for flour and noodle enterprises, but is small compared with the maximum number (67) registered with the DIW (2019). There is no significant difference in the workload of each employee, and the minimum wage of $\$ 11$ day per person is paid to all employees. The manager and his nephew manage the whole process, and are responsible for other vital tasks such as contract management, quality control, and the shipment of noodles. 
Prior to implementing process control, Factory A received complaints two to three times a year about noodle liquefaction from the buyers and other noodle producers. If liquefaction occurs, the producers cannot sell any noodles made in the same lot. Moreover, it may take up to a month to solve the liquefaction problem through trial and error. Given the focus placed on the $\mathrm{pH}$ of flour and washing water after implementing process control, Factory A has since experienced virtually no occurrences of liquefaction.

Moreover, the manager studied prevention techniques and interacted with researchers in Thailand and abroad. Factory A uses scientific methods to prevent noodle liquefaction. For instance, they conduct $\mathrm{pH}$ tests every day to monitor and manage the $\mathrm{pH}$ levels at several points in the production process, and wash boiled noodles using water containing acetic acid with a low $\mathrm{pH}$ level. Although Factory A incorporates some unique features in its production process, the whole procedure is almost the same as that of traditional SMEs.

Factory A's production process is not certified under any scheme. Good Manufacturing Practice (GMP) is the basic food safety standard for food manufacturers, as regulated by the Food and Drug Administration in Thailand (Ratanakorn et al. 2016). Rice vermicelli (categorized as a low-risk product) does not require food registration but can apply general GMPs (Ratanakorn et al. 2016). ${ }^{2}$ Manufactures certified with GMP or HACCP can use the Q Mark through the certification scheme of the National Bureau of Agricultural Commodity and Food Standards (ACFS 2018). However, the requirements of these programs may be too severe in terms of equipment and system for SMEs using traditional

${ }^{2}$ Other food standards such as Hazard Analysis and Critical Control Points (HACCP), International Organization for Standardization (ISO) 9001, and ISO 2200 are positioned as higher-level sanitary standards (Ratanakorn et al. 2016). manufacturing methods.

\section{Factory A's supply chain}

Factory A uses $5,500 \mathrm{~kg}$ of rice to produce $6,600 \mathrm{~kg}$ of flour, of which $6,000 \mathrm{~kg}$ is sold and $600 \mathrm{~kg}$ is processed into noodles within a day. Noodle production is estimated at $828 \mathrm{~kg} /$ day, based on operating one automatic noodle-making machine for eight hours a day.

Noodle production is a profitable sector for Factory A: although the processing only uses $9 \%$ of produced flour, its contribution margin ratio is significantly higher than that of flour production, as discussed below (Fig. 1). The factory sells noodles mainly to an agent, as well as to a market and a few individuals.

Flour is traded via market-based transactions, whereas noodles are mainly traded via customer transactions. There are no written contracts between buyers and producers. Thus, even though the primary cause of noodle liquefaction is yet to be identified, once liquefaction occurs in khanom jeen production, the noodle manufacturers who purchased processed fermented rice flour from Factory A would suspend payment for the flour.

\section{Method of determining the cost structure and liquefaction effects}

This study used the income statement for management accounting to conduct cost-volume-profit analysis or breakeven analysis (Eldenburg et al. 2016) for assessing the underlying cost structure, and the effects of suspended sales and reduced production caused by noodle liquefaction.

A model reflecting the cost structure of Factory A simulates the effects of suspended sales and reduced production on small-scale flour and noodle producers (see Fig. 2, Table S1). The model first provides a decreasing rate of the sold quantity, which determines the sales value. The sold quantity sequentially affects the

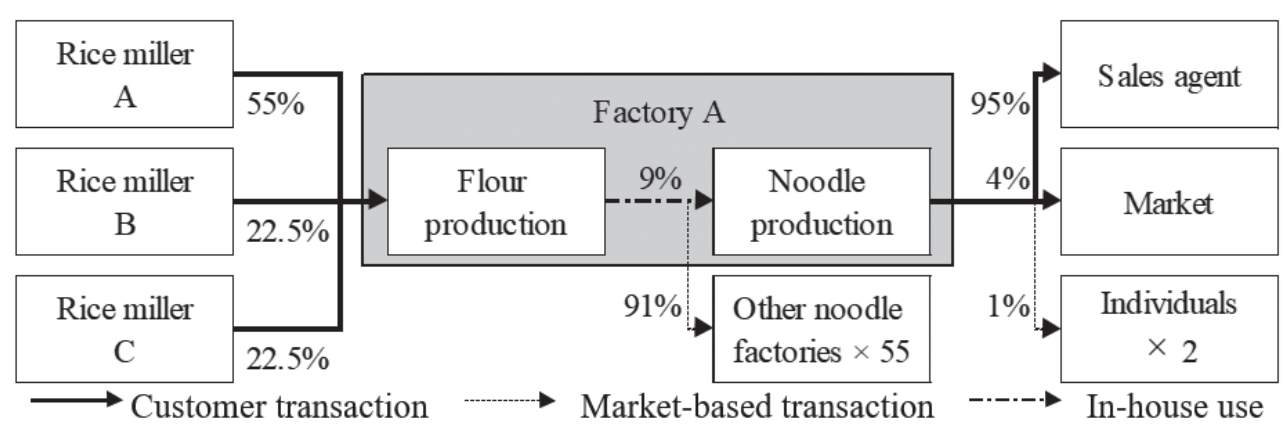

Fig. 1. Distribution channel of Factory A for rice flour and noodles Percentage (\%) denotes the proportion of total product weight. 
quantities for sales and production, and the variable costs. Most variable costs are defined as linear functions of production or the quantity for sales, which is not necessarily the same as the sold quantity.

Producers cannot receive payment for flour or noodles for the day that liquefaction occurs, but can save on variable costs by reducing their production for up to two weeks after the event in this model. The model simulates the profit and margin of the safety ratio regarding the following four types of production processes: (1) flour production using purchased raw material rice, and sale of products at different prices as in Factory A; (2) noodle production only using free flour, and sale of products at $\$ 0.43 / \mathrm{kg}$ to the agent ${ }^{3}$ as in Factory A; (3) noodle production only using flour purchased at the market price of $\$ 0.58 / \mathrm{kg}$, and sale of products at $\$ 0.43 / \mathrm{kg}$ to the agent ("noodle production 1 "); and (4) noodle production only using flour purchased at $\$ 0.58 / \mathrm{kg}$, and sale of products at $\$ 0.66 / \mathrm{kg}^{4}$ to the agent ("noodle production 2").

\section{Cost structures of Factory A and model management}

Variable costs account for much of the cost in both flour and noodle production (Table 1). The margin of safety is high for both flour and noodle production, in the range of $77 \%-78 \%$. This implies that profits become losses when product sales drop below the $77 \%-78 \%$

\footnotetext{
${ }^{3}$ The average selling prices are as follows: agent $=\$ 0.43 / \mathrm{kg}$, market $=\$ 0.83 / \mathrm{kg}$, individuals $=\$ 0.66 / \mathrm{kg}$, and workers (not fit for sale) $=\$ 0.33 / \mathrm{kg}$.

${ }^{4}$ The selling price of $\$ 0.66 / \mathrm{kg}$ is the same as that for individuals.
}

range, the breakeven point. However, the safety margin of "noodle production 2 " is lower at $47 \%$, indicating that management is more vulnerable to external shocks, such as an increase in raw material, fuel, and labor costs.

The contribution margin ratio of noodle production is significantly high when the internalized flour production process is free of cost. Meanwhile, the independent production of noodles using flour bought from another company at the market price is not profitable ("noodle production 1"). The contribution margin ratio of independent noodle production is still lower than that of independent flour production, even when the price of noodles sold to the agent increases from $\$ 0.43 / \mathrm{kg}$ to $\$ 0.66 / \mathrm{kg}$ ("noodle production 2").

\section{Effect of suspended sales on profit and safety margin}

Monthly profits steadily decrease as the unsold volume and number of days of reduced production increase (Fig. 3). The effect of a sales decrease on profits is larger than that of a temporary suspension of production on variable cost savings. The profit of a flour producer not receiving payment for $100 \%$ of the flour produced on a specific day will drop by $\$ 3,710$ (16\% of monthly profit), and will increase to a total amount of $\$ 11,976$ (51\% of monthly profit) if production is suspended the following week. Similarly, the profit of a noodle producer purchasing flour ("noodle production 2 ") decreases by $\$ 587$ (30\%) from non-receipt of payment for $100 \%$ of the noodles, and will reach $\$ 1,159$ $(59 \%)$ in total if production is suspended the following week. As with the effect on profit, the greater the margin of safety decreases, the larger the unsold volume and

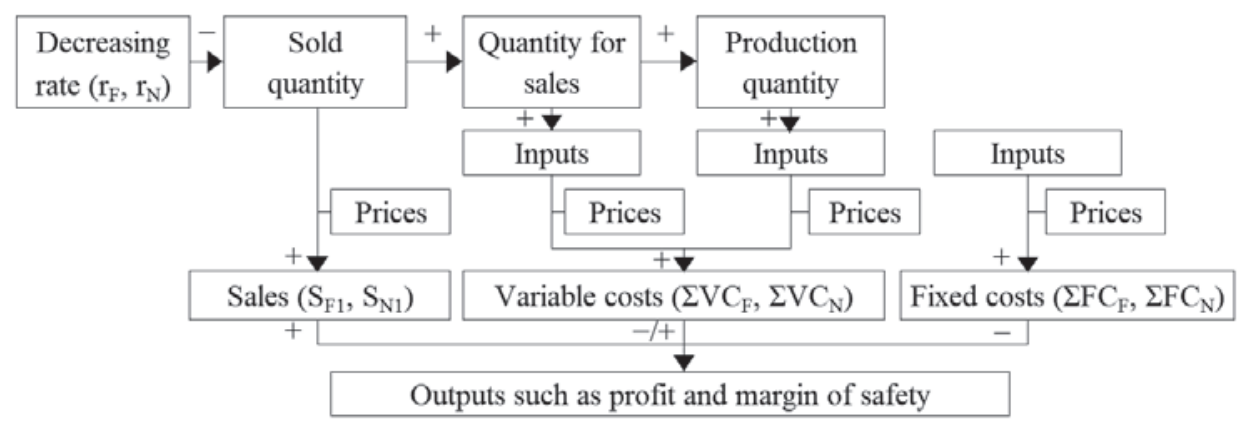

Fig. 2. Conceptual chart of the model

"Sold quantity" affects "Quantity for sales," depending on the scenario. See Table S1 for details about the equations in parentheses. Symbols "+" and "-_" denote positive and negative relations, respectively. The variable and fixed costs affect profit negatively. The margin of safety increases as the sales increase, total costs decrease, or the proportion of variable costs increases when total costs are constant. Thus, variable costs can have both negative and positive effects on the margin of safety. 
Quality Management for Business Stability of a Thai Noodle Company

Table 1. Estimated income statement of Factory A, monthly average in 2019 (\$/month)

\begin{tabular}{|c|c|c|c|c|c|}
\hline & \multicolumn{3}{|c|}{ Production of flour and noodle } & \multirow{2}{*}{$\begin{array}{l}\text { (3) Noodle } \\
\text { production } 1\end{array}$} & \multirow{2}{*}{$\begin{array}{l}\text { (4) Noodle } \\
\text { production } 2\end{array}$} \\
\hline & Total & (1) Flour & (2) Noodle & & \\
\hline Profit $\left(\mathrm{S}_{\mathrm{PRD} 1}-\mathrm{C}_{\mathrm{PRD}}\right)$ & 30,761 & 23,324 & 7,437 & $-3,700$ & 1,962 \\
\hline Sales $\left(\mathrm{S}_{\mathrm{PRD1} 1}\right)$ & 123,678 & 111,613 & 12,065 & 12,065 & 17,728 \\
\hline Total cost $\left(\mathrm{C}_{\mathrm{PRD}}=\Sigma \mathrm{VC}_{\mathrm{PRD}}+\Sigma \mathrm{FC}_{\mathrm{PRD}}\right)$ & 92,917 & 88,289 & 4,628 & 15,765 & 15,765 \\
\hline Variable cost $\left(\Sigma \mathrm{VC}_{\mathrm{PRD}}\right)$ & 83,947 & 81,529 & 2,418 & 13,555 & 13,555 \\
\hline Rice / flour ( $\left.\mathrm{VC}_{\mathrm{PRD1}}\right)$ & 73,718 & 73,718 & 0 & 11,137 & 11,137 \\
\hline Additives $\left(\mathrm{VC}_{\mathrm{PRD} 2}\right)$ & 2,495 & 2,487 & 8 & 8 & 8 \\
\hline Packing materials $\left(\mathrm{VC}_{\mathrm{PRD} 3}\right)$ & 3,228 & 1,789 & 1,439 & 1,439 & 1,439 \\
\hline Electricity tariff $\left(\mathrm{VC}_{\mathrm{PRD} 4}\right)$ & 1,877 & 1,105 & 773 & 773 & 773 \\
\hline Diesel cost $\left(\mathrm{VC}_{\mathrm{PRD} 5}\right)$ & 1,661 & 1,462 & 198 & 198 & 198 \\
\hline Labor wage $\left(\mathrm{VCP}_{\mathrm{RD} 6}\right)$ & 968 & 968 & 0 & 0 & 0 \\
\hline Fixed cost $\left(\Sigma \mathrm{FC}_{\mathrm{PRD}}\right)$ & 8,970 & 6,760 & 2,210 & 2,210 & 2,210 \\
\hline Equipment / consumables $\left(\mathrm{FC}_{\mathrm{PRD1}}\right)$ & 392 & 389 & 3 & 3 & 3 \\
\hline Machines $\left(\mathrm{FC}_{\mathrm{PRD} 2}\right)$ & 661 & 649 & 12 & 12 & 12 \\
\hline Facilities $\left(\mathrm{FC}_{\mathrm{PRD} 3}\right)$ & 273 & 272 & 0 & 0 & 0 \\
\hline Building / land $\left(\mathrm{FC}_{\mathrm{PRD} 4}\right)$ & 557 & 516 & 42 & 42 & 42 \\
\hline Water cost $\left(\mathrm{FC}_{\mathrm{PRD} 5}\right)$ & 299 & 289 & 10 & 10 & 10 \\
\hline Automobile cost $\left(\mathrm{FC}_{\mathrm{PRD} 6}\right)$ & 112 & 84 & 28 & 28 & 28 \\
\hline Labor wages $\left(\mathrm{FC}_{\mathrm{PRD} 7}\right)$ & 6,664 & 4,559 & 2,104 & 2,104 & 2,104 \\
\hline $\mathrm{pH}$ test $\left(\mathrm{FC}_{\mathrm{PRD} 8}\right)$ & 12 & 1 & 11 & 11 & 11 \\
\hline Contribution margin & 39,731 & 30,084 & 9,647 & $-1,490$ & 4,173 \\
\hline Breakeven point & 27,923 & 25,080 & 2,764 & - & 9,390 \\
\hline Contribution margin ratio (\%) & 32 & 27 & 80 & - & 24 \\
\hline Breakeven point ratio (\%) & 23 & 22 & 23 & - & 53 \\
\hline Margin of safety (\%) & 77 & 78 & 77 & - & 47 \\
\hline
\end{tabular}

See the text body for numbers in parentheses indicating scenarios. Production of flour and noodles: Price of flour to produce noodles $=0$. Price of noodles for agent $=\$ 0.43 / \mathrm{kg}$. (3) Noodle production 1: Price of flour to produce noodles $=\$ 0.58 / \mathrm{kg}$. Price of noodles for agent $=\$ 0.43 / \mathrm{kg}$. (4) Noodle production 2: Price of flour to produce noodles $=\$ 0.58 / \mathrm{kg}$. Price of noodles for agent $=$ $\$ 0.66 / \mathrm{kg}$. See Table S1 for details about the equations in parentheses. Subscript "PRD" denotes the product type and takes the symbol "F" (flour) or "N" (noodles).

Contribution margin $=$ Sales - Variable cost. Breakeven point $=$ Fixed cost $/($ Contribution margin ratio/100). Contribution margin ratio $=$ Contribution margin/Sales $\times 100$. Breakeven point ratio $=$ Breakeven point $/$ Sales $\times 100$. Margin of safety $=100-$ Breakeven point ratio.

higher the number of reduced production days (Fig. 4).

The profit of noodle producers who must purchase raw material flour may decrease significantly even when they need not pay for the flour as compensation for the suspended production. Their non-payment for raw material flour would mitigate the drop in monthly profit from $\$ 1,375$ to $\$ 1,746$ on any one day (Table 2$)$. However, even if they need not pay for the flour, their suspension of noodle production for one or two weeks will reduce their monthly profit to $\$ 1,174$ or $\$ 602$, respectively. Thus, flour and noodle producers should fundamentally focus on products that have low liquefaction risk, so as to avoid a substantial drop in profits. 
E. Kusano et al.

(1) Flour production

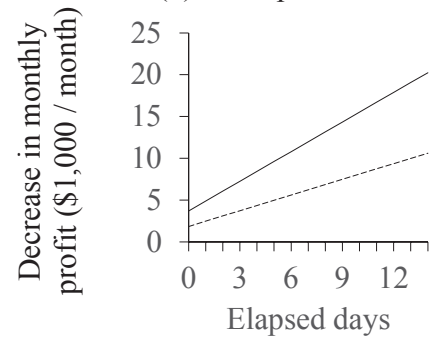

(2) Noodle production

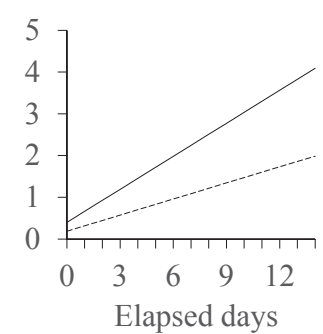

50
(4) Noodle production 2

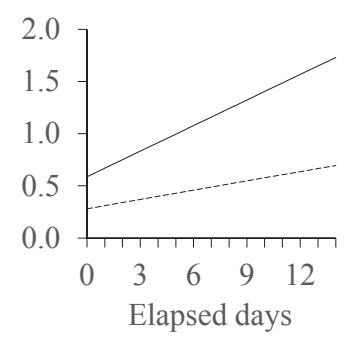

100

Fig. 3. Estimated decrease in monthly profit

(3) Noodle production 1 is omitted. See the text body for numbers in parentheses indicating scenarios.

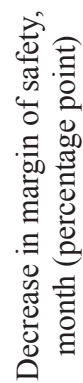

(1) Flour production

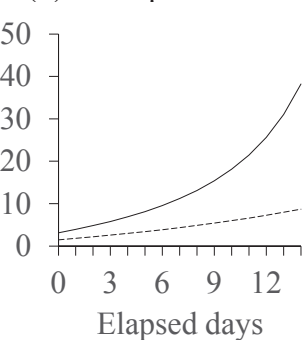

(2) Noodle production

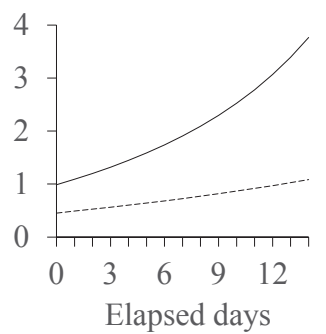

(4) Noodle production 2

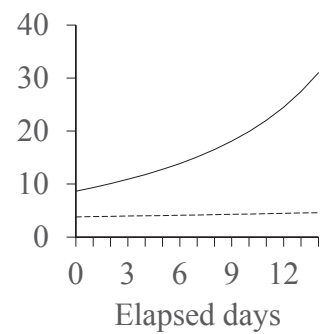

Decrease in daily sales quantity (\%) 500

Fig. 4. Estimated decrease in margin of safety ratio

(3) Noodle production 1 is omitted. See the text body for numbers in parentheses indicating scenarios.

Table 2. Effect of non-payment for rice flour on the income statement of (4) Noodle production 2 (\$/month)

\begin{tabular}{|c|c|c|c|c|c|}
\hline \multirow{2}{*}{$\begin{array}{l}\text { Payment for rice flour } \\
\text { Days to stop only sales }\end{array}$} & \multicolumn{2}{|c|}{ Payment } & \multicolumn{3}{|c|}{ Non-payment } \\
\hline & 0 & 1 & 1 & 1 & 1 \\
\hline Days to stop sales and production & 0 & 0 & 0 & 7 & 14 \\
\hline Profit & 1,962 & 1,375 & 1,746 & 1,174 & 602 \\
\hline Sales & 17,728 & 17,140 & 17,140 & 13,015 & 8,891 \\
\hline Total cost & 15,765 & 15,765 & 15,395 & 11,841 & 8,288 \\
\hline Variable cost & 13,555 & 13,555 & 13,185 & 10,127 & 7,070 \\
\hline Rice / flour & 11,137 & 11,137 & 10,767 & 8,175 & 5,584 \\
\hline Others & 2,418 & 2,418 & 2,418 & 1,952 & 1,486 \\
\hline Fixed cost & 2,210 & 2,210 & 2,210 & 1,714 & 1,218 \\
\hline Contribution margin ratio $(\%)$ & 24 & 21 & 23 & 22 & 20 \\
\hline Margin of safety $(\%)$ & 47 & 38 & 44 & 41 & 33 \\
\hline
\end{tabular}

\section{Quality control based on $\mathrm{pH}$ measurement}

Various technologies, such as controlling the $\mathrm{pH}$ level and water activity, pasteurization, and packaging, can improve the microbial stability of fermented rice noodles (Chinkrua 2011). This study focuses on preventing liquefaction by controlling the $\mathrm{pH}$ level in the production process.

\section{Method and cost of $\mathrm{pH}$ measurement}

Frequent $\mathrm{pH}$ level measurements at critical points of the production process can capture and prevent the 
risk of liquefaction. The expenses incurred for $\mathrm{pH}$ level measurement are quite small (Fig. 5) compared to the other costs mentioned earlier (see Table 2), even when measurements are taken at several points. ${ }^{5}$ Inexpensive and easy-to-use digital $\mathrm{pH}$ meters are especially useful in case of a relatively large number of measuring points. However, the cost of the $\mathrm{pH}$ indicator paper increases linearly with the number of measuring points.

\section{Systematic prevention of liquefaction through $\mathrm{pH}$ measurement}

Systematic monitoring of $\mathrm{pH}$ levels can be beneficial in avoiding liquefaction. If water shows a high $\mathrm{pH}$ level, the water $\mathrm{pH}$ level should be carefully checked and adjusted. The flour producer should also monitor

\footnotetext{
${ }^{5}$ Factory A measured the $\mathrm{pH}$ level of products before packing and boiling the fermented rice flour, and the water containing acetic acid used for washing boiled noodles every day.
}

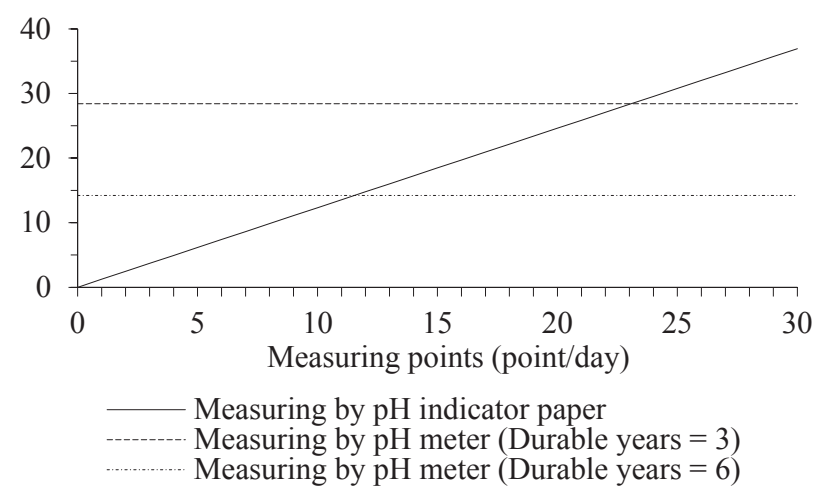

Fig. 5. Monthly average costs for measuring $\mathrm{pH}$ (\$/month)

Assumptions for the calculation are as follows:

(1) Measuring $\mathrm{pH}$ every business day $=361$ (days/year)/12 (months) $=30.08$ (days/month).

(2) Unit price of $\mathrm{pH}$ indicator paper $(5 \mathrm{~m})=\$ 10.23$. Length of paper for one measurement $=2 \mathrm{~cm}$.

(3) Unit price of $\mathrm{pH}$ meter $=\$ 1,023.1,000$-hour operation by AAA battery $\times 3$. Measuring time for one measurement $=5$ seconds.

(4) Unit price of AAA battery for $\mathrm{pH}$ meter $=\$ 1.65$.

(5) Cost of measuring $\mathrm{pH}$ by indicator paper (\$/month) $=$ Cost of one measurement $(\$ /$ point $) \times$ Measuring points (points/day) $\times$ Measuring days (days/month) $=\$ 0.0409 /$ point $\times$ Measuring points $($ points $/$ day $) \times$ 30.08 (days/month). Cost of measuring $\mathrm{pH}$ by meter $(\$ /$ month $)=$ Cost of one measurement $(\$ /$ point $) \times$ Measuring points (points/day) $\times$ Measuring days (days/month) + Price of $\mathrm{pH}$ meter (\$)/Durable months $($ months $)=\$ 2.31 \times 10^{-6} /$ point $\times$ Measuring points (points/day) $\times 30.08$ (days/month) $+\$ 1,023 /$ Durable months (months). and manage the fermentation. A high $\mathrm{pH}$ level in products just after solid- or liquid-state fermentation indicates something abnormal in the process that needs corrective action through review operations.

Noodle producers can lower the $\mathrm{pH}$ level of products during the production process. One practical method is to wash the noodles with low $\mathrm{pH}$ level water after the boiling process, as done in Factory A. Factory A washed $830 \mathrm{~kg}$ of noodles per day with groundwater mixed with acetic acid having a pH level of 4 after three successive preliminary washings with normal $\mathrm{pH}$ water and slightly low $\mathrm{pH}$ water. When the washing procedure follows that of Factory A, the cost of the acid water used is $\$ 7 /$ month, which is lower than the cost of adding the maximum level of $0.1 \%$ benzoate, a common food preservative, to noodles (Fig. 6; Bureau of Food, FDA Thailand 2018). Note that the amount of acetic acid used depends on the water quality at each site and the flavor of the noodles.

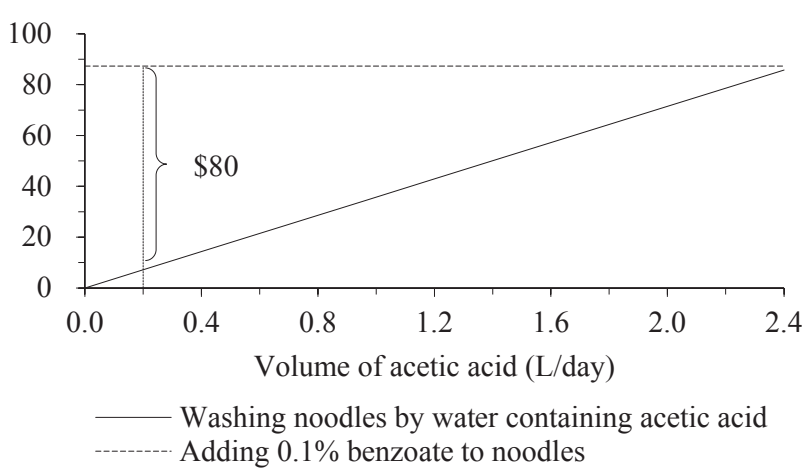

Fig. 6. Monthly average costs for preventing liquefaction of $830 \mathrm{~kg}$ of noodles per day (\$/month)

Assumptions for the calculation are as follows:

(1) Producing noodles every business day $=30.08$ (days/month).

(2) Produced noodles $=830 \mathrm{~kg} /$ day.

(3) Unit price of acetic acid $=\$ 29.70 / 25 \mathrm{~L}=\$ 1.19 / \mathrm{L}$.

(4) Unit price of benzoate $=\$ 3.50 / \mathrm{kg}$. Adding $0.1 \%$ of benzoate to the noodles.

(5) Cost of acetic acid $(\$ /$ month $)=$ Volume of acetic acid $(\mathrm{L} /$ day $) \times$ Unit price of acetic acid $(\$ / \mathrm{L}) \times$ Producing days $($ days $/$ month $)=$ Volume of acetic acid $(\mathrm{L} /$ day $) \times \$ 1.19 / \mathrm{L} \times 30.08$ (days $/$ month) .

(6) Cost of benzoate $(\$ /$ month $)=$ Volume of noodles $(\mathrm{kg} /$ day $) \times$ Percentage of benzoate $(\%) \times$ Unit price of benzoate $(\$ / \mathrm{kg}) \times$ Producing days (days $/$ month $)=$ $830(\mathrm{~kg} /$ day $) \times 0.1 \% \times \$ 3.50 / \mathrm{kg} \times 30.08$ (days/ month) $\approx \$ 87 /$ month. When $0.2 \mathrm{~L} /$ day acetic acid is used for washing noodles, the gap between the cost of using $0.1 \%$ benzoate and washing by water containing acetic acid is $\$ 80 /$ month. 


\section{Conclusions}

The adoption of new technology is often discussed from the perspective of innovation as being critical in responding to the evolving buyer requirements of both products and processes, and for improving the competitiveness of food producers. Conventional small producers find it relatively easy to accept manufacturerfriendly techniques in terms of business management and technological capability.

This case study showed that both fermented rice flour and noodle producers could essentially operate with a low risk of liquefaction and improve their business management. The instability of product quality, particularly noodle liquefaction, severely impacts the profitability of flour and noodle producers; the lower the sales quantity and longer the reduced production period due to liquefaction, the more significant the negative impacts on profitability. Furthermore, the non-payment for flour by noodle producers cannot be the fundamental solution to unstable profitability.

The primary management of the production process involves securing product shelf life in the market as well as profitability. Frequent $\mathrm{pH}$ measurement at appropriate production process points is the first relatively inexpensive step to preventing liquefaction. And engaging in practices intended to reduce high $\mathrm{pH}$ levels incorporated at appropriate points can also reduce the risk of liquefaction. One such practice is using a liquid having a low $\mathrm{pH}$ level to wash the noodles. The cost of this procedure is lower than that of using common food preservatives. Flour producers need to eliminate the factors inhibiting fermentation, instead of simply lowering the noodle's $\mathrm{pH}$ level when identified as being high at critical fermentation points.

The findings of this study are based on the data for one small-scale noodle producer. Therefore, the results of this study should not be generalized without carefully considering business differences in terms of technologies and capabilities. Moreover, this study does not show the trajectory of autonomous technology development and adoption by SMEs; it merely indicates the appropriateness of a specific technique in terms of business management. There would be many other techniques to consider, along with limiting the issue to the shelf life of khanom jeen. Although not the focus of this study, the effects of liquefaction and adoption of technology on buyer confidence should also be investigated.

Nonetheless, this study is worthwhile in concretely presenting how systemized basic quality management can stabilize food product quality in a developing economy. Detailed information on specific technologies, equipment needed for implementation, and associated costs can shed light on the relation between food science and agribusiness management, thereby supporting research on discussing the pathways of adopting technology in more generalized ways.

\section{References}

Baregheh, A. et al. (2012) Food sector SMEs and innovation types. Brit. Food. J., 114, 1640-1653.

Baregheh, A. et al. (2014) Towards an integrative view of innovation in food sector SMEs. Int. J. Entrepreneurship Innov., 15, 147-158.

Bureau of Food, Food and Drug Administration Thailand (2018) Notification of Ministry of Public Health (No. 389) B.E. 2561 (2018) Re: food additives (No. 5). http://www. fda.moph.go.th/sites/food/SitePages/FoodAdditives.aspx [In Thai].

Chinkrua, P. (2011) Development of ready-to-eat Kanom Jeen. Master thesis, Chulalongkorn University, Bangkok, Thailand.

Dale, B. G. (2003) Managing quality, $4^{\text {th }}$ edition. Blackwell Publishing, Malden, USA, pp. 21-27.

Dasthanim, W. (2018) Customer satisfaction towards marketing mix of rice noodle flour, Tiger Brand of Khanomjeen South Company Limited. Independent Research Article, Faculty of Business Administration, Ramkhamhaeng University. http://www.ba-abstract.ru.ac.th/index.php/abstractData/ viewIndex/216.ru [In Thai with English abstract].

Eldenburg, L. G. et al. (2016) Management accounting, $3^{\text {rd }}$ edition. John Wiley \& Sons Australia, Ltd, Milton, Australia.

Fryer, P. J. \& Versteeg, C. (2008) Processing technology innovation in the food industry. Innovation, 10, 74-90.

Huq, M. \& Toyama, M. (2006) An analysis of factors influencing the development of new products in the Thai food industry. TMSD, 5, 159-172.

Marui, J. et al. (2020) pH-dependent liquefaction of Thai fermented rice noodles (khanom jeen) associated with bacterial amylolytic enzymes. JARQ, 54, 41-45.

Ngamkroeckjoti, C. et al. (2005) Environmental scanning in Thai food SMEs: The impact of technology strategy and technology turbulence. Brit Food J, 107, 285-305.

OECD \& World Bank (2017) Inclusive global value chains: Policy options in trade and complementary areas for GVC integration by small and medium enterprises and lowincome developing countries. The World Bank, Washington, D.C., USA.

Office of Small and Medium Enterprises Promotion (OSMEP) (2018) SME white paper 2018. https://www.sme.go.th/th/ download.php?modulekey=215 [In Thai].

Oupathumpanont, O. et al. (2009) Screening lactic acid bacteria for improving the kanom-jeen process. Kasetsart Journal (Natural Science), 43, 557-565.

Ratanakorn, S. et al. (2016) Food Regulations and Enforcement in Thailand. Reference Module in Food Science. Elsevier. http://dx.doi.org/10.1016/B978-0-08-100596-5.21147-5.

Roungchong, J. et al. (2020) Satisfaction toward marketing mix (7Ps) of Thai tourists Kanom Jeen restaurants in Mueang District, Nakhon Si Thammarat Province. Rajamangala 
Quality Management for Business Stability of a Thai Noodle Company

University of Technology Tawan-ok Social Science Journal, 9, 9-19 [In Thai with English abstract].

Suwannaporn, P. \& Speece, M. (2010) Assessing new product development success factors in the Thai food industry. Brit Food J, 112, 364-386.

The Department of Industrial Works, Ministry of Industry (DIW) (2019) Factory information. http://www.diw.go.th/ hawk/content.php?mode=data1 search.

The National Bureau of Agricultural Commodity and Food Standards (ACFS) (2010) Database of food consumption of Thai people, version 1.0.6. http://61.19.221.35/index. php?lang=eng. Accessed on 8 May 2020.

The National Bureau of Agricultural Commodity and Food
Standards (ACFS) (2018) Handbook of agricultural product certification standards under the Agricultural Product Standards Act 2008, Third edition. https://tascode.acfs. go.th/index.php/about/6-handbookdl [In Thai].

Uchimura, T. et al. (1991) Identification of lactic acid bacteria isolated from fermented rice noodle "khanom jeen" of Thailand. Nippon Shokuhin Kogyo Gakkaishi (J. Jpn. Soc. Food Sci.), 38, 465-475 [In Japanese with English abstract]. Vyas, V. (2015) Low-cost, low-tech innovation: New product development in the food industry. Routledge Studies in Innovation, Organizations and Technology, Routledge, Abingdon, UK.

Supplementary material: Table S1. Model structure

\begin{tabular}{ccccc}
\hline \hline Item & Value & Volume & Symbol & $\begin{array}{c}\text { Equations } \\
\text { (volume or electricity) }\end{array}$ \\
\hline
\end{tabular}

\section{Flour production}

Sales

Rice flour, sold

Rice flour, for sales

Rice flour, for noodles

Rice flour, produced

Variable cost

Rice, total

Rice A

Rice B

Rice C

Broken rice

Additives

Salt

Others

Packing materials

Electricity tariff

Diesel cost

Labor wage (driver)

Fixed cost

Equipment/consumables

Tank for soaking rice, 1 ton

Tank for soaking rice, 2.5 tons

Plastic basket with plastic sheet

Spare parts, flour milling machine

Filter, filtration machine

Filter, filter press

Metal container for dewatered paste

Scale

Plastic pallet for bagged flour

Trolley

Hose to move paste and water (white)

$\begin{array}{rrll}111,613 & 6,000 & \mathrm{~kg} / \text { day } & \mathrm{S}_{\mathrm{F} 1} \\ - & 6,000 & \mathrm{~kg} / \text { day } & \mathrm{S}_{\mathrm{F} 2} \\ - & 599 & \mathrm{~kg} / \text { day } & \mathrm{S}_{\mathrm{F} 3} \\ - & 6,600 & \mathrm{~kg} / \text { day } & \mathrm{S}_{\mathrm{F} 4} \\ & & & \\ 73,718 & 5,500 & \mathrm{~kg} / \text { day } & \mathrm{VC}_{\mathrm{F} 1} \\ 33,218 & 2,500 & \mathrm{~kg} / \text { day } & \mathrm{VC}_{\mathrm{F} 1,1} \\ 16,609 & 1,250 & \mathrm{~kg} / \text { day } & \mathrm{VC}_{\mathrm{F} 1,2} \\ 17,938 & 1,250 & \mathrm{~kg} / \text { day } & \mathrm{VC}_{\mathrm{F} 1,3} \\ 5,953 & 500 & \mathrm{~kg} / \text { day } & \mathrm{VC}_{\mathrm{F} 1,4} \\ 2,487 & 390 & \mathrm{~kg} / \text { day } & \mathrm{VC}_{\mathrm{F} 2} \\ 797 & 375 & \mathrm{~kg} / \text { day } & \mathrm{VC}_{\mathrm{F} 2,1} \\ 1,690 & 15 & \mathrm{~kg} / \text { day } & \mathrm{VC}_{\mathrm{F} 2,2} \\ 1,789 & 330 & \text { unit/day } & \mathrm{VC}_{\mathrm{F} 3} \\ 1,105 & 243 & \mathrm{kWh} / \text { day } & \mathrm{VC}_{\mathrm{F} 4} \\ 1,462 & 55 & \text { L/day } & \mathrm{VC}_{\mathrm{F} 5} \\ 968 & 3 & \text { unit/day } & \mathrm{VC}_{\mathrm{F} 6} \\ & & & \\ 389 & - & & \mathrm{FC}_{\mathrm{F} 1} \\ 9 & 4 & \text { unit } & \mathrm{FC}_{\mathrm{F} 1,1} \\ 40 & 18 & \text { unit } & \mathrm{FC}_{\mathrm{F} 1,2} \\ 149 & 1,350 & \text { unit } & \mathrm{FC}_{\mathrm{F} 1,3} \\ 18 & 2 & \text { unit } & \mathrm{FC}_{\mathrm{F} 1,4} \\ 7 & 2 & \text { unit } & \mathrm{FC}_{\mathrm{F} 1,5} \\ 13 & 2 & \text { unit } & \mathrm{FC}_{\mathrm{F} 1,6} \\ 22 & 2 & \text { unit } & \mathrm{FC}_{\mathrm{F} 1,7} \\ 48 & 2 & \text { unit } & \mathrm{FC}_{\mathrm{F} 1,8} \\ & 30 & \text { unit } & \mathrm{FC}_{\mathrm{F} 1,9} \\ & 75 & \text { unit } & \mathrm{FC}_{\mathrm{F} 1,10} \\ & & \text { unit } & \mathrm{FC}_{\mathrm{F} 1,11}\end{array}$

$$
\begin{aligned}
& \left(1-\mathrm{r}_{\mathrm{F}}\right) \cdot \mathrm{S}_{\mathrm{F} 1} * \\
& \mathrm{~S}_{\mathrm{F} 2} * \text { or } \mathrm{S}_{\mathrm{F} 1} \\
& \mathrm{~S}_{\mathrm{F} 3} * \mathrm{~S}_{\mathrm{N} 1} / \mathrm{S}_{\mathrm{N} 1} * \\
& \mathrm{~S}_{\mathrm{F} 2}+\mathrm{S}_{\mathrm{F} 3} \\
& \Sigma \mathrm{VC}_{\mathrm{F} 1, \mathrm{j}} \\
& \mathrm{VC}_{\mathrm{F} 1,1} * \mathrm{~S}_{\mathrm{F} 4} / \mathrm{S}_{\mathrm{F} 4} * \\
& \mathrm{VC}_{\mathrm{F} 1,2} * \mathrm{~S}_{\mathrm{F} 4} / \mathrm{S}_{\mathrm{F} 4} * \\
& \mathrm{VC}_{\mathrm{F} 1,3} * \mathrm{~S}_{\mathrm{F} 4} / \mathrm{S}_{\mathrm{F} 4} * \\
& \mathrm{VC}_{\mathrm{F} 1,4} * \mathrm{~S}_{\mathrm{F} 4} / \mathrm{S}_{\mathrm{F} 4} * \\
& \Sigma \mathrm{VC}_{\mathrm{F} 2, \mathrm{j}} \\
& \mathrm{VC}_{\mathrm{F} 2,1} * \mathrm{~S}_{\mathrm{F} 4} / \mathrm{S}_{\mathrm{F} 4} * \\
& \mathrm{VC}_{\mathrm{F} 2,2} * \mathrm{~S}_{\mathrm{F} 4} / \mathrm{S}_{\mathrm{F} 4} * \\
& \mathrm{VC}_{\mathrm{F} 3} \cdot \mathrm{S}_{\mathrm{F} 4} / \mathrm{S}_{\mathrm{F} 4} * \\
& \mathrm{EFC}_{\mathrm{F} 2}+0.97 \mathrm{EFC} \mathrm{P} \\
& 26.2 \mathrm{VC}_{\mathrm{F} 6} \\
& \mathrm{VC}_{\mathrm{F} 6} * \mathrm{~S}_{\mathrm{F} 2} / \mathrm{S}_{\mathrm{F} 2} *
\end{aligned}
$$

$\mathrm{FC}_{\mathrm{F} 1}$

$\mathrm{FC}_{\mathrm{F} 1,2}$

$\mathrm{FC}_{\mathrm{F} 1,3}$

$\mathrm{FC}_{\mathrm{F} 1,4}$

$\mathrm{FC}_{\mathrm{F} 1,7}$

$\mathrm{FC}_{\mathrm{F} 1,8}$

$\mathrm{FC}_{\mathrm{F} 1,10}$

$\mathrm{FC}_{\mathrm{F} 1,11}$ 
( Continued)

\begin{tabular}{|c|c|c|c|c|c|}
\hline Item & $\begin{array}{l}\text { Value } \\
(\$ / \mathrm{m})\end{array}$ & \multicolumn{2}{|c|}{ Volume } & \multirow{2}{*}{$\begin{array}{c}\text { Symbol } \\
\mathrm{FC}_{\mathrm{F} 1,12}\end{array}$} & \multirow{2}{*}{$\begin{array}{c}\text { Equations } \\
\text { (volume or electricity) }\end{array}$} \\
\hline Hose to move paste and water (blue) & 26 & 15 & unit & & \\
\hline Machines & 649 & - & & $\mathrm{FC}_{\mathrm{F} 2}$ & $\mathrm{EFC}_{\mathrm{F} 2}=\Sigma \mathrm{EFC}_{\mathrm{F} 2, \mathrm{j}}$ \\
\hline Flour milling machine & 385 & 2 & unit & $\mathrm{FC}_{\mathrm{F} 2,1}$ & $\mathrm{EFC}_{\mathrm{F} 2,1}=\mathrm{FC}_{\mathrm{F} 2,1} \cdot 10 \cdot 5 \cdot \mathrm{S}_{\mathrm{F} 4} / \mathrm{S}_{\mathrm{F} 4} *$ \\
\hline Pump to move paste and water & 37 & 4 & unit & $\mathrm{FC}_{\mathrm{F} 2,2}$ & $\mathrm{EFC}_{\mathrm{F} 2,2}=\mathrm{FC}_{\mathrm{F} 2,2} \cdot 1.5 \cdot 5 \cdot \mathrm{S}_{\mathrm{F} 4} / \mathrm{S}_{\mathrm{F} 4} *$ \\
\hline Stilling machine & 17 & 6 & unit & $\mathrm{FC}_{\mathrm{F} 2,3}$ & $\mathrm{EFC}_{\mathrm{F} 2,3}=\mathrm{FC}_{\mathrm{F} 2,3} \cdot 1.5 \cdot 3 \cdot \mathrm{S}_{\mathrm{F} 4} / \mathrm{S}_{\mathrm{F} 4} *$ \\
\hline Filtration machine & 1 & 2 & unit & $\mathrm{FC}_{\mathrm{F} 2,4}$ & $\mathrm{EFC}_{\mathrm{F} 2,4}=\mathrm{FC}_{\mathrm{F} 2,4} \cdot 1.5 \cdot 5 \cdot \mathrm{S}_{\mathrm{F} 4} / \mathrm{S}_{\mathrm{F} 4} *$ \\
\hline Filter press & 69 & 2 & unit & $\mathrm{FC}_{\mathrm{F} 2,5}$ & $\mathrm{EFC}_{\mathrm{F} 2,5}=\mathrm{FC}_{\mathrm{F} 2,5} \cdot 1.5 \cdot 7 \cdot \mathrm{S}_{\mathrm{F} 4} / \mathrm{S}_{\mathrm{F} 4} *$ \\
\hline Tying machine for flour bag & 1 & 1 & unit & $\mathrm{FC}_{\mathrm{F} 2,6}$ & $\mathrm{EFC}_{\mathrm{F} 2,6}=\mathrm{FC}_{\mathrm{F} 2,6} \cdot 0.3 \cdot 2 \cdot \mathrm{S}_{\mathrm{F} 4} / \mathrm{S}_{\mathrm{F} 4} *$ \\
\hline Forklift, electromotion & 138 & 1 & unit & $\mathrm{FC}_{\mathrm{F} 2,7}$ & $\mathrm{EFC}_{\mathrm{F} 2,7}=\mathrm{FC}_{\mathrm{F} 2,7} \cdot 19 \cdot 2 \cdot \mathrm{S}_{\mathrm{F} 4} / \mathrm{S}_{\mathrm{F} 4} *$ \\
\hline Fan for air conditioning & 3 & 4 & unit & $\mathrm{FC}_{\mathrm{F} 2,8}$ & $\mathrm{EFC}_{\mathrm{F} 2,8}=\mathrm{FC}_{\mathrm{F} 2,8} \cdot 0.3 \cdot 8 \cdot \mathrm{S}_{\mathrm{F} 4} / \mathrm{S}_{\mathrm{F} 4} *$ \\
\hline Facilities & 272 & - & & $\mathrm{FC}_{\mathrm{F} 3}$ & \\
\hline Wooden shelves for baskets & 11 & - & & $\mathrm{FC}_{\mathrm{F} 3,1}$ & \\
\hline Concrete tank for rice fermentation & 14 & 3 & unit & $\mathrm{FC}_{\mathrm{F} 3,2}$ & \\
\hline Concrete tank for paste fermentation & 248 & 6 & unit & $\mathrm{FC}_{\mathrm{F} 3,3}$ & \\
\hline Building/land & 516 & - & & $\mathrm{FC}_{\mathrm{F} 4}$ & \\
\hline Building A for flour production & 458 & 1 & unit & $\mathrm{FC}_{\mathrm{F} 4,1}$ & \\
\hline Building B for flour production & 55 & 1 & unit & $\mathrm{FC}_{\mathrm{F} 4,2}$ & \\
\hline Land tax & 2 & - & & $\mathrm{FC}_{\mathrm{F} 4,3}$ & \\
\hline Water cost & 289 & - & & $\mathrm{FC}_{\mathrm{F} 5}$ & \\
\hline Polyaluminium chloride & 6 & 0.3 & $\mathrm{~kg} /$ day & $\mathrm{FC}_{\mathrm{F} 5,1}$ & \\
\hline Water preparation & 177 & - & & $\mathrm{FC}_{\mathrm{F} 5,2}$ & \\
\hline Wastewater & 106 & - & & $\mathrm{FC}_{\mathrm{F} 5,3}$ & \\
\hline Automobile cost & 84 & - & & $\mathrm{FC}_{\mathrm{F} 6}$ & \\
\hline Automobile depreciation & 46 & 3 & unit & $\mathrm{FC}_{\mathrm{F} 6,1}$ & \\
\hline Automobile maintenance fee & 38 & 3 & unit & $\mathrm{FC}_{\mathrm{F} 6,2}$ & \\
\hline Labor wage (processor) & 4,559 & 13 & unit/day & $\mathrm{FC}_{\mathrm{F} 7}$ & \\
\hline $\mathrm{pH}$ test ( $\mathrm{pH}$ test strips roll) & 1 & 1 & time/day & $\mathrm{FC}_{\mathrm{F} 8}$ & \\
\hline \multicolumn{6}{|l|}{ Noodle production } \\
\hline \multicolumn{6}{|l|}{ Sales } \\
\hline Rice noodles sold (including "for worker") & 17,728 & 820 & $\mathrm{~kg} /$ day & $\mathrm{S}_{\mathrm{N} 1}$ & $\left(1-\mathrm{r}_{\mathrm{N}}\right) \cdot \mathrm{S}_{\mathrm{N} 1} *$ \\
\hline $0.5 \mathrm{~kg} \times 10$ baskets & 5,448 & 50 & unit/day & $\mathrm{S}_{\mathrm{N} 1,1}$ & $\mathrm{~S}_{\mathrm{N} 1,1} * \mathrm{~S}_{\mathrm{N} 1} / \mathrm{S}_{\mathrm{N} 1} *$ \\
\hline $1 \mathrm{~kg} \times 6$ baskets & 3,221 & 25 & unit/day & $\mathrm{S}_{\mathrm{N} 1,2}$ & $\mathrm{~S}_{\mathrm{N} 1,2} * \mathrm{~S}_{\mathrm{N} 1} / \mathrm{S}_{\mathrm{N} 1} *$ \\
\hline $2 \mathrm{~kg}$ & 2,147 & 50 & unit/day & $\mathrm{S}_{\mathrm{N} 1,3}$ & $\mathrm{~S}_{\mathrm{N} 1,3} * \mathrm{~S}_{\mathrm{N} 1} / \mathrm{S}_{\mathrm{N} 1} *-$ Fraction $_{2}$ \\
\hline $3 \mathrm{~kg}$ & 1,929 & 30 & unit/day & $\mathrm{S}_{\mathrm{N} 1,4}$ & $\mathrm{~S}_{\mathrm{N} 1,4} * \mathrm{~S}_{\mathrm{N} 1} / \mathrm{S}_{\mathrm{N} 1} *$ \\
\hline $5 \mathrm{~kg}$ & 4,278 & 40 & unit/day & $\mathrm{S}_{\mathrm{N} 1,5}$ & $\mathrm{~S}_{\mathrm{N} 1,5} * \mathrm{~S}_{\mathrm{N} 1} / \mathrm{S}_{\mathrm{N} 1} *$ \\
\hline $10 \mathrm{~kg}$ & 638 & 3 & unit/day & $\mathrm{S}_{\mathrm{N} 1,6}$ & $\mathrm{~S}_{\mathrm{N} 1,6} * \mathrm{~S}_{\mathrm{N} 1} / \mathrm{S}_{\mathrm{N} 1} *$ \\
\hline Rice noodles, for sales & - & 820 & $\mathrm{~kg} /$ day & $\mathrm{S}_{\mathrm{N} 2}$ & $\mathrm{~S}_{\mathrm{N} 2} *$ or $\mathrm{S}_{\mathrm{N} 1}$ \\
\hline Rice noodles, loss & - & 8 & kg/day & $\mathrm{S}_{\mathrm{N} 3}$ & $0.01 \mathrm{~S}_{\mathrm{N} 2}+$ Fraction $_{1}$ \\
\hline Rice noodle, for worker & 66 & 8 & $\mathrm{~kg} /$ day & $\mathrm{S}_{\mathrm{N} 3,1}$ & $\mathrm{FC}_{\mathrm{F} 7}+\mathrm{FC}_{\mathrm{N} 7}\left(\right.$ Upper limit $\left.=\mathrm{S}_{\mathrm{N} 3}\right)$ \\
\hline Rice noodles, waste & - & 0 & $\mathrm{~kg} /$ day & $\mathrm{S}_{\mathrm{N} 3,2}$ & $\mathrm{~S}_{\mathrm{N} 3}-\mathrm{S}_{\mathrm{N} 3,1}$ \\
\hline Rice noodles, produced & - & 828 & $\mathrm{~kg} /$ day & $\mathrm{S}_{\mathrm{N} 4}$ & $\mathrm{~S}_{\mathrm{N} 2}+\mathrm{S}_{\mathrm{N} 3}$ \\
\hline \multicolumn{6}{|l|}{ Variable cost } \\
\hline Rice flour, for noodle production & 11,137 & 599 & kg/day & $\mathrm{VC}_{\mathrm{N} 1}$ & $\Sigma \mathrm{VC}_{\mathrm{N} 1, \mathrm{j}}$ \\
\hline Flour, produced & 0 & 0 & $\mathrm{~kg} / \mathrm{day}$ & $\mathrm{VC}_{\mathrm{N} 1,1}$ & $\mathrm{~S}_{\mathrm{F} 3}$ or 0 \\
\hline
\end{tabular}

( Continued on next page ) 
( Continued )

\begin{tabular}{|c|c|c|c|c|c|}
\hline Item & Value & \multicolumn{2}{|c|}{ Volume } & \multirow{2}{*}{$\begin{array}{l}\text { Symbol } \\
\mathrm{VC}_{\mathrm{N} 1,2}\end{array}$} & \multirow{2}{*}{$\begin{array}{c}\begin{array}{c}\text { Equations } \\
\text { (volume or electricity) }\end{array} \\
0 \text { or } \mathrm{S}_{\mathrm{F} 3}\end{array}$} \\
\hline Flour, purchased & 11,137 & 599 & $\mathrm{~kg} /$ day & & \\
\hline Additives (acetic acid) & 8 & 0.2 & L/day & $\mathrm{VC}_{\mathrm{N} 2}$ & $\mathrm{VC}_{\mathrm{N} 2} * \mathrm{~S}_{\mathrm{N} 4} / \mathrm{S}_{\mathrm{N} 4} *$ \\
\hline Packing materials & 1,439 & & & $\mathrm{VC}_{\mathrm{N} 3}$ & $\Sigma \mathrm{VC}_{\mathrm{N} 3, \mathrm{j}}$ \\
\hline Baskets and bags for selling noodles & 1,226 & 198 & unit/day & $\mathrm{VC}_{\mathrm{N} 3,1}$ & $\Sigma \mathrm{VC}_{\mathrm{N} 3,1, \mathrm{j}}$ \\
\hline $0.5 \mathrm{~kg} \times 10$ baskets & 542 & 50 & unit/day & $\mathrm{VC}_{\mathrm{N} 3,1,1}$ & $\mathrm{VC}_{\mathrm{N} 3,1,1} * \mathrm{~S}_{\mathrm{N} 2} / \mathrm{S}_{\mathrm{N} 2} *$ \\
\hline $1 \mathrm{~kg} \times 6$ baskets & 198 & 25 & unit/day & $\mathrm{VC}_{\mathrm{N} 3,1,2}$ & $\mathrm{VC}_{\mathrm{N} 3,1,2} * \mathrm{~S}_{\mathrm{N} 2} / \mathrm{S}_{\mathrm{N} 2} *$ \\
\hline $2 \mathrm{~kg}$ & 139 & 50 & unit/day & $\mathrm{VC}_{\mathrm{N} 3,1,3}$ & $\mathrm{VC}_{\mathrm{N} 3,1,3} * \mathrm{~S}_{\mathrm{N} 2} / \mathrm{S}_{\mathrm{N} 2} *-$ Fraction $_{2}$ \\
\hline $3 \mathrm{~kg}$ & 115 & 30 & unit/day & $\mathrm{VC}_{\mathrm{N} 3,1,4}$ & $\mathrm{VC}_{\mathrm{N} 3,1,4} * \mathrm{~S}_{\mathrm{N} 2} / \mathrm{S}_{\mathrm{N} 2} *$ \\
\hline $5 \mathrm{~kg}$ & 207 & 40 & unit/day & $\mathrm{VC}_{\mathrm{N} 3,1,5}$ & $\mathrm{VC}_{\mathrm{N} 3,1,5} * \mathrm{~S}_{\mathrm{N} 2} / \mathrm{S}_{\mathrm{N} 2} *$ \\
\hline $10 \mathrm{~kg}$ & 25 & 3 & unit/day & $\mathrm{VC}_{\mathrm{N} 3,1,6}$ & $\mathrm{VC}_{\mathrm{N} 3,1,6} * \mathrm{~S}_{\mathrm{N} 2} / \mathrm{S}_{\mathrm{N} 2} *$ \\
\hline Logo label & 213 & 773 & unit/day & $\mathrm{VC}_{\mathrm{N} 3,2}$ & $\mathrm{VC}_{\mathrm{N} 3,2} * \mathrm{~S}_{\mathrm{N} 2} / \mathrm{S}_{\mathrm{N} 2} *$ \\
\hline Electricity tariff & 773 & 170 & $\mathrm{kWh} /$ day & $\mathrm{VC}_{\mathrm{N} 4}$ & $\mathrm{EFC}_{\mathrm{N} 2}+0.03 \mathrm{EFC}_{\mathrm{P}}$ \\
\hline Diesel cost & 198 & 17 & L/day & $\mathrm{VC}_{\mathrm{N} 5}$ & $17.3 \mathrm{VC}_{\mathrm{N} 6}$ \\
\hline Labor wage (driver) & 0 & 1 & unit/day & $\mathrm{VC}_{\mathrm{N} 6}$ & $\mathrm{VC}_{\mathrm{N} 6} * \mathrm{~S}_{\mathrm{N} 2} / \mathrm{S}_{\mathrm{N} 2} *$ \\
\hline \multicolumn{6}{|l|}{ Fixed cost } \\
\hline Equipment/consumables & 3 & - & & $\mathrm{FC}_{\mathrm{N} 1}$ & \\
\hline Bucket for soaking flour & 1 & 5 & unit & $\mathrm{FC}_{\mathrm{N} 1,1}$ & \\
\hline Plastic tank for water & 0.1 & 1 & unit & $\mathrm{FC}_{\mathrm{N} 1,2}$ & \\
\hline Plastic tank for water with acid & 0.3 & 2 & unit & $\mathrm{FC}_{\mathrm{N} 1,3}$ & \\
\hline Scale & 2 & 1 & unit & $\mathrm{FC}_{\mathrm{N} 1,4}$ & \\
\hline Machine (noodle-making machine) & 12 & 1 & unit & $\mathrm{FC}_{\mathrm{N} 2}$ & $\mathrm{EFC}_{\mathrm{N} 2}=\mathrm{FC}_{\mathrm{N} 2} \cdot 20 \cdot 8 \cdot \mathrm{S}_{\mathrm{N} 4} / \mathrm{S}_{\mathrm{N} 4} *$ \\
\hline Facilities (wooden tables) & 0.4 & - & & $\mathrm{FC}_{\mathrm{N} 3}$ & \\
\hline Building/land & 42 & - & & $\mathrm{FC}_{\mathrm{N} 4}$ & \\
\hline Building & 41 & 1 & unit & $\mathrm{FC}_{\mathrm{N} 4,1}$ & \\
\hline Land tax & 1 & - & & $\mathrm{FC}_{\mathrm{N} 4,2}$ & \\
\hline Water cost & 10 & - & & $\mathrm{FC}_{\mathrm{N} 5}$ & \\
\hline Water preparation & 6 & - & & $\mathrm{FC}_{\mathrm{N} 5,1}$ & \\
\hline Wastewater & 4 & - & & $\mathrm{FC}_{\mathrm{N} 5,2}$ & \\
\hline Automobile cost & 28 & - & & $\mathrm{FC}_{\mathrm{N} 6}$ & \\
\hline Automobile depreciation & 15 & 1 & unit & $\mathrm{FC}_{\mathrm{N} 6,1}$ & \\
\hline Automobile maintenance fee & 13 & 1 & unit & $\mathrm{FC}_{\mathrm{N} 6,2}$ & \\
\hline Labor cost (processor) & 2,104 & 6 & unit/day & $\mathrm{FC}_{\mathrm{N} 7}$ & \\
\hline pH test (pH test strips roll) & 11 & 9 & time/day & $\mathrm{FC}_{\mathrm{N} 8}$ & \\
\hline
\end{tabular}

This table lists the values under scenario (1) for the flour and scenario (4) for the noodles as described in the text body. $m=$ month. $\mathrm{r}=$ assumed decreasing rate for flour and for noodles. $\mathrm{EFC}_{\mathrm{P}}=$ electricity cost for pumping groundwater. Fraction $\mathrm{n}_{1}(\mathrm{~kg})=$ noodles weighing less than $2 \mathrm{~kg}$, the minimum selling unit. Fraction ${ }_{2}(\mathrm{bag})=1$ when Fraction $_{1}(\mathrm{~kg})>0$.

Symbols with superscript * are fixed to values in the column "Volume". Equations for $\mathrm{S}_{\mathrm{F} 2}, \mathrm{~S}_{\mathrm{N} 2}, \mathrm{VC}_{\mathrm{N} 1,1}, \mathrm{VC}_{\mathrm{N} 1,2}$ depend on the scenarios. Equations beginning with the letter "E" in the "Machines" row express consumed energy (kWh/day).

"Value" and "Volume" in the table are those in the normal operating period (after this normal period; see the text). The estimated monthly values shown in the text are based on daily, monthly, or annual normal period sales. Estimated monthly value = $\Sigma$ (Standardized daily value ${ }_{i}$ Day $_{i} /$ Month), where i denotes value on the day of normal production and sales, normal production and decrease in sales, or reduction in production and sales. Standardized daily values are estimated by three different methods according to the original data as follows:

1. Original data are daily data: Standardized daily value $=$ Daily value[Day $\left.{ }_{j}+\operatorname{Day}_{k}\left(\operatorname{Hour}_{k} / \operatorname{Hour}_{j}\right)\right]=$ Daily value[293 $\left.+68(11 / 8)\right]$, where $\mathrm{j}$ denotes the normal period, and $\mathrm{k}$ denotes the busy period. Values in the normal period are fundamentally calculated by the following equation: Value $=$ Price $\cdot$ Volume.

2. Original data are monthly data: Standardized daily value = Monthly value·12/Operating days of 361 . 
E. Kusano et al.

3. Original data are the purchasing prices of durables: Standardized daily value $=($ Purchased price/Durable years·Number $) /$ Operating days of 361 .

Consumed energy of individual machines in the flour and noodle production process, excluding that of the charged energy for $\mathrm{FC}_{\mathrm{F} 2,7}$, are estimated by $\mathrm{FC}_{\mathrm{F}, \mathrm{j}} \cdot \mathrm{PC}_{\mathrm{i}, \mathrm{j}} \cdot \mathrm{OT}_{\mathrm{i}, \mathrm{j}} \cdot \mathrm{S}_{\mathrm{F} 4} / \mathrm{S}_{\mathrm{F} 4} *$ or $\mathrm{FC}_{\mathrm{Ni}} \cdot \mathrm{PC}_{\mathrm{i}} \cdot \mathrm{OT}_{\mathrm{i}} \cdot \mathrm{S}_{\mathrm{N} 4} / \mathrm{S}_{\mathrm{N} 4} *$, where $\mathrm{PC}$ denotes power consumption (kW/unit/hour), OT denotes operation time on a normal day (hour/unit/day), and subscripts $i$ and $j$ denote specific machines. Electricity tariff is calculated as follows: Base tariff $+\mathrm{F}_{\mathrm{t}}+\mathrm{VAT}$, where $\mathrm{F}_{\mathrm{t}}(-0.116)$ denotes the fuel tariff or fuel adjustment tariff rate in 2019, and $\mathrm{VAT}=1.07$. Base tariff is calculated using the equation of the "Normal tariff with consumption exceeding $150 \mathrm{kWh}$ per month" for "Residential Service" of the Metropolitan Electricity Authority (2020).

Expenses for land tax and electricity for preparing water, such as pumping, are allocated to flour and noodle production processes based on the distribution of land (flour: noodle $=79.7: 20.3)$ and water (97.0: 3.0).

\section{Reference}

Metropolitan Electricity Authority (2020) Small general service. https://www.mea.or.th/en/profile/109/112. 